\title{
Influence of Host Plants on the Development of Caryedon serratus Olivier (Coleoptera: Chrysomelidae, Bruchinae), Insect Pest of Groundnut Stocks in Burkina Faso
}

\author{
Issoufou Ouedraogo ${ }^{*}$, Sacamba Aimé Omer Hema1, Wendgoundi Guenda², Dona Dakouo ${ }^{1}$ \\ ${ }^{1}$ INERA/Station de Farako-Bâ, Bobo-Dioulasso, Burkina Faso \\ ${ }^{2}$ UFR-SVT, Université de Ouagadougou, Ouagadougou, Burkina Faso \\ Email: ${ }^{\star}$ yeguere@yahoo.com
}

How to cite this paper: Ouedraogo, I., Hema, S.A.O., Guenda, W. and Dakouo, D. (2016) Influence of Host Plants on the Development of Caryedon serratus Olivier (Coleoptera: Chrysomelidae, Bruchinae), Insect Pest of Groundnut Stocks in Burkina Faso. Advances in Entomology, 4, 279-292. http://dx.doi.org/10.4236/ae.2016.45029

Received: July 27, 2016

Accepted: October 23, 2016

Published: October 26, 2016

Copyright $\odot 2016$ by authors and Scientific Research Publishing Inc. This work is licensed under the Creative Commons Attribution International License (CC BY 4.0).

http://creativecommons.org/licenses/by/4.0/ (c) (i) Open Access

\begin{abstract}
The beetle Caryedon serratus Olivier is a major insect pest responsible for the infestation and damage on groundnut during storage. To understand the infestation mechanism of groundnut stocks, studies have been carried out on this insect biology under laboratory conditions in relation with its host plants. The results have demonstrated that the pre-oviposition on groundnut lasts on average 1.28 days. The oviposition period is 12.04 days, during which 80.42 eggs on average are laid. From hatching to adult stage, $C$. serratus larvae development goes through four stages with variable durations according to the stage. Three families of host plants (Papilionaceae; Caesalpiniaceae and Mimosaceae) were selected for females $C$. serratus to lay on their seeds. The results showed that more eggs were laid on the seeds of Papilionaceae $(98.75 \%$ of infested seeds) followed by Caesalpiniaceae $(28.59 \%$ of infested seeds). Studies were carried out on the laying behavior of $C$. serratus under laboratory conditions and have revealed that whatever the conditions, $C$. serratus females lay on all the plant species seeds exposed. Insects' development duration has varied according to the plant species seeds used.
\end{abstract}

\section{Keywords}

Groundnut, Storage, Caryedon serratus, Biology, Burkina Faso

\section{Introduction}

In Sahelian countries in general and Burkina Faso in particular, groundnut is one of the 
most cultivated and consumed leguminous plant. Burkina Faso is one of the main groundnut producers in Africa, with a production of 335,223 tons in 2014. This crop is very important in our country's rural economy because, more than a food crop, it's also a cash crop for farmers. In fact, groundnut seeds, containing approximately $50 \%$ of fat acids and $25 \%$ of proteins [1], constitute with shea butter and cotton seed oil, the main sources of lipids for the local populations in Burkina Faso. In spite of a growing production, groundnut remains out of the reach of consumers at some periods of the year. This paradox is justified by multiple constraints related not only to production, like lack of well-structured commercial channels, but also to issues related to the storage of this crop. Groundnut is attacked by several insect pests during storage which cause important losses [2] [3] [4] [5]. Among these insect pests, the Caryedon serratus Olivier beetle is the most important and the rare insects capable to attack unshelled groundnuts [6] [7] [8] [9]. The importance of the damage caused by this pest during storage explains why the scientific researches devoted to it [10]. However, in Burkina Faso where groundnut production of is important, very little work exists on this insect which presence was previously announced by several authors [7] [11]. In fact, this insect's distribution and its bio-ecology are not well-known although its presence is established. To purpose reducing damage caused by this beetle, research work on its biology its host plants' seeds and pods under Sahelian conditions have been carried out. The objective is not only to determine the influence of these laying substrates on the development of the groundnut beetle, but also to study the impact of these feeding supports available to the larvae on the development and the morphology of the adults. The final objective is to explain the infestation mechanisms of groundnut storages in farming areas.

\section{Methods}

\subsection{Plant Material}

The varieties of groundnut developed for their resistance to peanut rosette virus were used for our work (Table 1).

Table 1. Characteristics of groundnut specimen used.

\begin{tabular}{cccc}
\hline Varieties & Botanical classification & Vegetative cycle (days) & Nb seeds/pods \\
\hline CN 94C & Spanish & 90 & 2 \\
SH 470P & Spanish & 90 & 2 \\
59,426 & Virginia & $135-150$ & 2 \\
RMP 91 & Virginia & $135-150$ & $1-3$ \\
RMP 12 & Virginia & $135-150$ & $1-3$ \\
\hline
\end{tabular}

\section{Other Plant Material}

The plant materials used were from several host plants families. All the experiments were carried out with seeds belonging to various leguminous plants. Four of them belong to the family of Ceasalpiniaceae: Tamarindus indica (Linné), Bauhinia rufescens 
(Lam.), Cassia sieberiana (D.C), Piliostigma thonningü (Schum); five are from Mimosaceae: Acacia senegal (Lin.), Acacia gourmaensis (Lin.), Acacia nilotica var. tomentosa (Lin.), Acacia nilotica var adansonnii; Faidherbia albida (Chev.), and Prosopis africana (Guill.).

\subsection{Insects Used and Study Conditions}

The insects used are Caryedon serratus adults reared on groundnut varieties and on wild host plants.

To study C. serratus' development cycle, the research work was carried out in the laboratory where temperatures ranged about $29^{\circ} \mathrm{C} \pm 3^{\circ} \mathrm{C}$ with a relative humidity from 53 to 86 p.c.

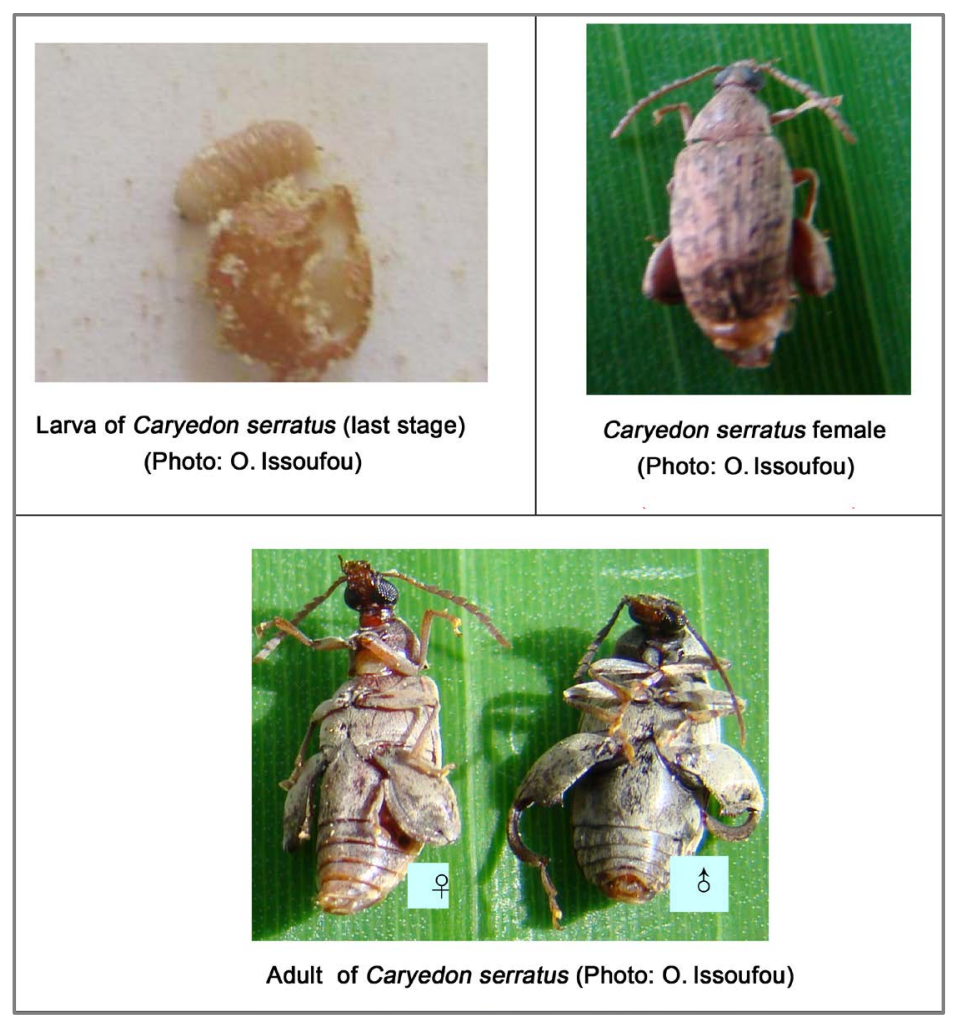

\subsubsection{Rearing of $C$. serratus on Wild Host Plants}

Rearing of $C$. serratus was carried out in two-litters Plexiglas bottles on fruits of the wild host plants. Pods of T. indica, B. rufescens and P. thonningii were used as laying and feeding supports. For each plant species a bottle closed with a very close mesh-net muslin cloth was used. Small openings are made on the bottle and are covered with a close mesh-net cloth to allow air circulation. The insects to be reared were taken from their original plants in the nature. After the first generation, adults were taken and identified by genitalia male method to be sure it is really $C$. serratus species.

\subsubsection{Rearing of $C$. serratus on the Groundnut Pods}

The rearing of $C$. serratus was carried out in wooden rectangular cages of $0.9 \mathrm{~m}$ over 
$0.50 \mathrm{~m}$ closed on both sides with mesh-net to facilitate ventilation. RMP12 and CN94C groundnut pods varieties were put in each cage. The beetles are kept for one week in the cages and exposed to the groundnut pods. The insects are withdrawn and the pods are observed to follow the evolution of eggs till the emergence of adults. Starting from the $30^{\text {th }}$ day after the laying, the pods are observed daily till the emergence of adults which are withdrawn and used for the various experiments.

\subsection{C. serratus Biological Parameters Study}

\subsubsection{Larval Development Duration}

To follow C. serratus development cycle, newly emerged couples (not older than $24 \mathrm{~h}$ ) are taken from the rearing cages. These couples are isolated in Petri-dishes for 24 hours. The insects are withdrawn and the groundnut pods are observed individually under binocular microscope to note the eggs effective presence. The pods are then isolated at a rate of one per flat-bottom tube and kept under observation in the rearing room. These pods are observed till the appearance of $C$. serratus adults. After emergence, insects are separated according to their sexes under binocular microscope by observation of the last abdominal segment. This method permits species identification [12].

\subsubsection{Pre-Oviposition, Oviposition and Post-Oviposition Durations}

To determine the pre-oviposition period, same age $C$. serratus couples are isolated in a Petri-dish containing CN94C variety one groundnut seed. These couples are daily exposed to a groundnut pod. The groundnut pod which was used as laying support was replaced daily and observed under binocular microscope to notice the eventual presence of eggs. This operation continues till the female death. The beginning of the emission of the first egg determines the pre-oviposition period and the post-oviposition is the period which separates the emission of the last egg and the female death. 50 couples were observed in order to determine $C$. serratus biological parameters.

\subsubsection{C. serratus Different Larval Stages Duration}

To determine $C$. serratus exact larval development duration of each stage, $C$. serratus couples were isolated on sets of 100 groundnut pods during 12 hours. Four sets of 100 pods were used making 400 pods. After this period, the insects were withdrawn and the groundnut pods were observed under binocular microscope to determine the effective presence of eggs. During these observations, only one egg was kept by pod and the other eggs were destroyed. The groundnut pods were then divided into several collections of 10 pods with the same laying date. Five days after the laying and every 24 hours starting from this date, 10 pods were dissected in order to follow larvae evolution. Stages duration was given when a cephalic capsule was found in the cell of the larva. Thus, during the dissection of a groundnut seed, the presence of a cephalic cell is sought to mean that the larva moved from one stage to another.

\subsubsection{C. serratus Biological Parameters Study on the Wild Host Plants}

Five couples of $C$. serratus (not older than 24 hours) were exposed to the sets of wild host plants' seeds in a Petri-dish, without any water. Twenty grams of seeds of: $T$. indi- 
ca, B. rufescens, C. sieberiana, $P$. thonningii, $A$. senegal, $A$. gourmaensis, $A$. nilotica var tomentosa, $A$. nilotica var adansonnii, $F$. albida and $P$. africana were used for the experiment. Four repetitions were followed with the seeds of each plant used. The number of eggs laid by each female is counted at the end of three weeks. For the embryonic and post embryonic development durations, seeds presenting eggs were isolated in Petri-dishes and observed till adults emergence. At the emergence, species identification was done [12].

\subsection{Pod Size Influence on Caryedon serratus Laying}

C. serratus couples (not older than 48 hours) were maintained on groundnut and placed in three different bottles containing 100 pods of one-seed, two-seeds and threeseeds groundnut, respectively (Figure 1). At the end of three weeks laying, insects were withdrawn from the bottles and eggs were counted for each type of pods. Pods were then observed periodically to notice adults' emergence. When emerging, insects were measured according to the various types of pods by using an ocular micrometer with a binocular microscope. For the insects' measurement, their length and width were taken into account. This measurement required the calibration of the stage micrometer placed in the binocular microscope's objective. After calibration, the stage micrometer is placed in parallel with the reticle's divisions so that the two scales were superposed. Thereafter, the number of the reticle's divisions $(\mathrm{Y})$ which are superposed on the intervals of stage micrometer division $(\mathrm{X})$ was determined. Then the micrometric value was determined:

$$
A=(X / Y) \times \mathrm{I} ;
$$

I: Value in $\mathrm{mm}(0.1 \mathrm{~mm})$ of an interval of the stage micrometer.

Length of the insect $=A X$ Interval number of divisions of insect length reticle.

\subsection{Statistical Analysis}

The analyses of variance on the observed parameters were carried out by the Software

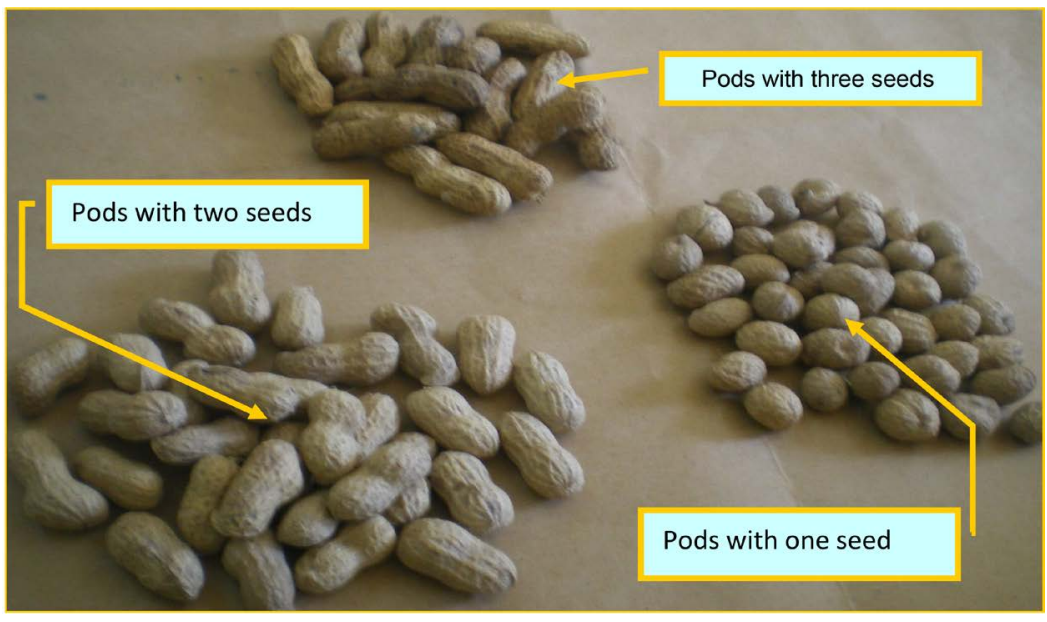

Figure 1. Different groundnut pods used during the experiments. 
XLSTAT version 2007. When the variance analysis revealed significant differences, the Fisher test (LSD) were applied for the comparison of averages at the probability threshold of $5 \%$.

\section{Results}

\subsection{C. serratus Biological Parameters Study on Its Host Plants}

\subsubsection{C. serratus Larval Development Duration on Groundnut}

C. serratus larval development duration from egg to adult is shown on the Table 2 . These results revealed that the $C$. serratus larval development varied on average 54.59 days for males versus 53.56 days for females with no statistical difference.

\subsubsection{Eggs Incubation Period}

The results (Table 2) indicate that eggs incubation period is 4.37 days on average; however some larvae spent 5 days to hatch. As for adults lifespan, males live longer (19.03 days old) than females (17.07 days old). The statistical analyses do not emphasize any significant difference between males and females lifespan. Larvae monitoring indicates that at emergence, females outweigh males hence a sex-ratio of 0.86 in favor of females, corresponding to 1 male for 1.16 females.

\subsubsection{Pre-Oviposition, Oviposition and Post-Oviposition Duration on Groundnut}

The results of pre-oviposition, oviposition and post-oviposition duration are presented on Table 3.

\subsubsection{Pre-Oviposition Duration}

Table 3 indicates that females spend on average 1.28 day after their emergence before laying. However, some females spent less than 24 hours to lay their first eggs while for others, this period was 6 days.

Table 2. C. serratus development duration (from egg to adult).

\begin{tabular}{ccccc}
\hline Sex & $\begin{array}{c}\text { Average duration for } \\
\text { egg hatch (days) }\end{array}$ & Number & $\begin{array}{c}\text { larval development average } \\
\text { duration (days) }\end{array}$ & $\begin{array}{c}\text { Adults lifespan } \\
\text { (days) }\end{array}$ \\
\hline Male & & 37 & $54.59 \pm 2.56 \mathrm{a}$ & $19.03 \pm 0.65 \mathrm{a}$ \\
Female & $4.37 \pm 0.70$ & 43 & $53.56 \pm 2.58 \mathrm{a}$ & $17.07 \pm 0.58 \mathrm{a}$ \\
Sex-ratio & & $1: 1.16$ & &
\end{tabular}

The averages ( \pm standard deviation) with the same letters in the same column do not differ significantly at the threshold of $5 \%$.

Table 3. C. serratus pre-oviposition, oviposition and post-oviposition period duration.

\begin{tabular}{ccccc}
\hline \multirow{2}{*}{$\begin{array}{c}\text { Number of females } \\
\text { monitored }\end{array}$} & \multicolumn{3}{c}{ Duration (days) } & \multirow{2}{*}{ Number of eggs } \\
\cline { 2 - 4 } 50 & Pre-oviposition & Oviposition & Post-oviposition & \\
\hline 50 & $4-6$ & $0-7$ & 4021 \\
Average & $1.28 \pm 0.14$ & $12.04 \pm 0.57$ & $4.34 \pm 0.42$ & $80.42 \pm 5.60$ \\
\hline
\end{tabular}




\subsubsection{Oviposition Duration}

The Table 3 showed that females laying lasted on average 12.04 days, but it was very variable from one female to another. In fact, some females spent 4 days to lay while for others, the laying period was extended over 20 days. As for the number of eggs laid, it was on average 80.42 eggs per female. The number of eggs laid by female varied from 2 to 189 eggs in relation to the female lifespan. C. serratus females post oviposition lasted on average 4.34 days, varying from 0 to 7 days after the laying period.

\subsubsection{Daily Eggs Laid by $C$. serratus Females on Groundnut}

The daily laying of the females showed an important variability during the oviposition period. The analysis of Figure 2 indicates that the laying duration can be divided into four periods. The maximum of eggs is laid during the first period which is the first four days following the pre oviposition. During this period, 767 eggs were laid, which account for $38.46 \%$ of eggs laid. Thereafter, a decrease of laying is observed during the five following days where the egg rate decreases to 634 eggs $(31.79 \%)$. The decrease of the laying is emphasized as from the $11^{\text {th }}$ day after the pre oviposition. The rate of eggs laid starting from this date constitutes $27.13 \%$ only. From the $18^{\text {th }}$ day after the laying beginning, the number of eggs accounts for only $2.60 \%$ (52 eggs laid during this period).

\subsection{C. serratus Larval Stage Duration on Groundnut}

C. serratus larval development study has permitted to show that the larva moves throughout four stages whose durations vary from one stage to another (Table 4).

After laying period, an average time of 4.37 days is observed before the larva passes through the husk to reach the groundnut seed. At stage 1, the larva spends on average

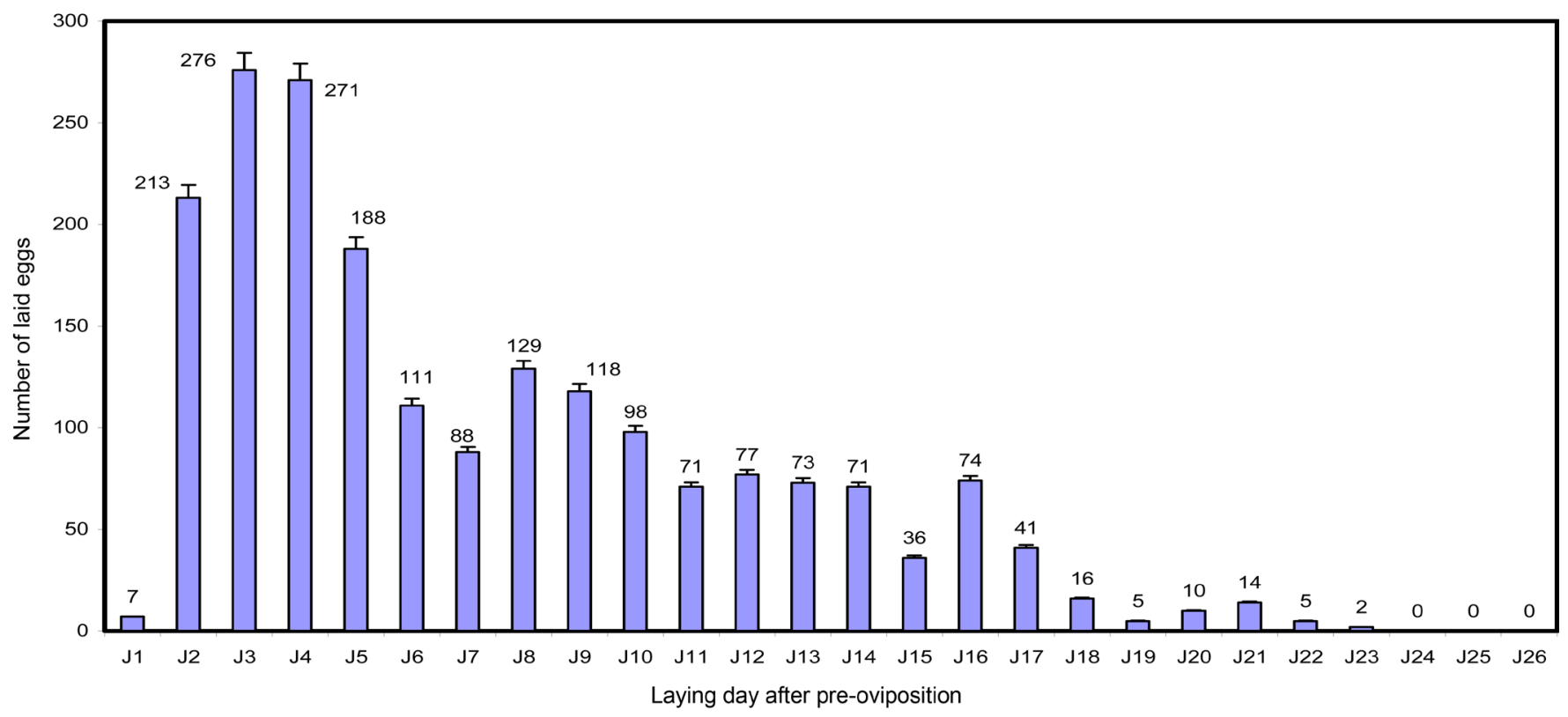

Figure 2. Evolution of daily laying average observed on 20 females of $C$. serratus on groundnut pods. 
Table 4. C. serratus larval stage duration.

\begin{tabular}{ccc}
\hline Larval stage & Number of larvae & $\begin{array}{c}\text { Average duration of } \\
\text { each larval stage } \\
\text { (days } \pm \text { SE) }\end{array}$ \\
\hline Stage 1 & 30 & $6.20 \pm 1.47$ \\
Stage 2 & 20 & $6.84 \pm 1.53$ \\
Stage 3 & 19 & $7.76 \pm 2.55$ \\
Stage 4 & 16 & $8.65 \pm 2.18$ \\
Pupation & 16 & $19.30 \pm 3.86$ \\
Total duration & & 48.75 \\
Average duration of eggs incubation & & 4.37 \\
\hline
\end{tabular}

6.20 days to develop. At stage 2, the development duration average was 6.84 days. Stage 3 lasts on average 7.76 days; at this stage, it can be noticed that the larvae are larger. After this stage, some larvae according to feeding support availability may infest new seeds. The fourth stage which precedes the larva entry into nymph stage lasts on average 8.65 days. The larva becomes even larger and become pink; often it gives up its initial pod to enter into nymph stage outside the pod. Nymphal stage duration, in our study, lasted on average 19.30 days.

\subsection{C. serratus Larval Development Duration on the Wild Host Plants}

C. serratus larval development duration from egg to adult stage was observed on whole seeds of the 10 wild host plants which were used in the context of our study. The results are given on Table 5 .

In all of the tested host plants, the larval development of the beetle was possible on only five host plants. Results on Table 5 indicate that the time between eggs deposit on various host plants seeds and adults' emergence varies from 36.40 to 55.33 days according to host plants nature. The longest larval development durations were observed with $B$. rufescens seeds ( 55.72 days). It is on $F$. alblida seeds that the larval development duration was the shortest with only 36.40 days. The number of adult insects emerged varied from 7 to 192 according to host plants. On the other host plants seeds, although eggs were laid, no larval development was observed after more than four months observation. Regardless of host plants, females outweigh males at emergence.

\subsection{Pod Type Influence on C. serratus Laying}

Results on Table 6 showed that eggs deposit was done regardless of pod type. However, the full number of eggs deposited on the pods with three seeds (443 eggs) is significantly higher than that recorded on the other types of pods $(\mathrm{P}<0.0001)$. Similarly, the laying on the pods with two seeds is more important than those obtained on pods with one seed. A total of 443 eggs on pods with three seeds, 310 eggs on pods with two seeds and 245 eggs on pods with one seed are obtained.

The adult emergence rate per type of pods was more important on pods with three 
Table 5. C. serratus larval development duration on the wild host plants.

\begin{tabular}{cccc}
\hline Host plants & $\begin{array}{c}\text { Average development } \\
\text { duration (days) }\end{array}$ & Number of emerged adults & Sex-ratio \\
\hline T. indica & $52.37 \pm 3.44$ & 192 & $1: 1.46$ \\
P. thonningii & $49.26 \pm 3.80$ & 18 & $1: 2.30$ \\
B. rufescens & $55.72 \pm 2.96$ & 29 & $1: 1.57$ \\
C. sieberiana & $55.33 \pm 3.36$ & 32 & $1: 0.66$ \\
F. albida & $36.40 \pm 2.14$ & 7 & $1: 2.50$ \\
\hline
\end{tabular}

Table 6. Pod type influence on Caryedon serratus various biological parameters.

\begin{tabular}{rccc}
\hline pods Type & Number of eggs & Rate of emergence (\%) & $\begin{array}{c}\text { Weight of 50 } \\
\text { individuals (g) }\end{array}$ \\
\hline One seed & 245 & 56 & 1.01 \\
Two seeds & 310 & 68.38 & 1.10 \\
Three seeds & 443 & 73.36 & 1.12 \\
\hline
\end{tabular}

seeds compared to the other types of pods. On pods with three seeds, the rate of emergence was $73.36 \%$ compared to $68.36 \%$ on pods with two seeds and $56 \%$ on pods with one seed. For adults emerged weight from the three types of pods, no significant difference was observed among them.

\subsection{Newly Emerged Adults Morphometry}

\subsubsection{Measurement of Insects Resulting from Groundnut}

Table 7 shows results on $C$. serratus adult emerged from groundnut pods measurement with one, two and three seeds.

Results observed on Table 7 for the average length and average width of emerged adults from groundnut pods of one seed, two seeds and three seeds are not significantly different $(\mathrm{P}>0.001)$. Results revealed that the average length of insects from the various types of pods varied from 5 to $7.5 \mathrm{~mm}$. On the other hand, it is on three-seeds pods that the average length of insects was the most important with $7.06 \mathrm{~mm}$. The average length for insects emerged from two-seeds pods was $6.57 \mathrm{~mm}$ versus $6.98 \mathrm{~mm}$ for individuals emerged from one-seed-pods. Regarding individuals' width, those resulting from three-seed pods had an average of $2.81 \mathrm{~mm}$ versus $2.76 \mathrm{~mm}$ for those with two seeds. One-seed groundnut pods had a $2.84 \mathrm{~mm}$ average adults' width.

\subsubsection{Measurement of Insects Resulting from Wild Host Plants}

Adult beetles measurement was also taken on the emerged insects from non-cultivated plants seeds; results are recorded on the Table 8.

\section{Discussion}

\subsection{C. serratus Biological Parameters Study on Groundnut under Laboratory Condition}

The results on $C$. serratus biology under laboratory conditions are similar to those 
Table 7. Average measurement of lately emerged adult from groundnut pods with one seed, two seeds and three seeds.

\begin{tabular}{cccc}
\hline Type of pods & Length $(\mathrm{mm})$ & Width $(\mathrm{mm})$ & Scale $(\mathrm{mm})$ \\
\hline One seed & $6.98 \pm 0.63 \mathrm{a}$ & $2.84 \pm 0.17 \mathrm{a}$ & $14.85 \pm 0.95 \mathrm{a}$ \\
Two seeds & $6.57 \pm 0.43 \mathrm{a}$ & $2.76 \pm 0.14 \mathrm{a}$ & $14.46 \pm 0.64 \mathrm{a}$ \\
Three seeds & $7.06 \pm 0.48 \mathrm{a}$ & $2.81 \pm 0.12 \mathrm{a}$ & $15.11 \pm 0.82 \mathrm{a}$ \\
\hline
\end{tabular}

Averages ( \pm standard deviation) with the same letters in the same column do not differ significantly at the threshold of $5 \%$.

Table 8. C. serratus adults emerged from different host plants measurement.

\begin{tabular}{cccc}
\hline Host plants & Length $(\mathrm{mm})$ & Width $(\mathrm{mm})$ & Scale $(\mathrm{mm})$ \\
\hline SH67A Seeds & $6.82 \pm 0.49 \mathrm{a}$ & $2.75 \pm 0.15 \mathrm{a}$ & $14.74 \pm 0.73 \mathrm{a}$ \\
T. indica & $6.35 \pm 0.57 \mathrm{~b}$ & $2.64 \pm 0.19 \mathrm{~b}$ & $14.07 \pm 1.07 \mathrm{a}$ \\
P. thonningii & $6.01 \pm 0.56 \mathrm{~b}$ & $2.50 \pm 0.17 \mathrm{~b}$ & $13.56 \pm 1.06 \mathrm{~b}$ \\
B. rufescens & $6.08 \pm 0.45 \mathrm{~b}$ & $2.47 \pm 0.21 \mathrm{~b}$ & $13.74 \pm 0.82 \mathrm{~b}$ \\
C. sieberiana & $5.62 \pm 0.34 \mathrm{~b}$ & $2.45 \pm 0.07 \mathrm{~b}$ & $13.32 \pm 0.72 \mathrm{~b}$ \\
F. albida & $6.05 \pm 0.28 \mathrm{~b}$ & $2.50 \pm 0.21 \mathrm{~b}$ & $12.36 \pm 1.19 \mathrm{c}$ \\
\hline
\end{tabular}

The averages ( \pm standard deviation) with the same letters in the same column do not differ significantly at the threshold of $5 \%$.

reported by many authors [13] [14]. The incubation period of eggs is similar to that reported by Robert [7] but it is the half of what was reported by Rama and Venugopal [13] who found an incubation time of 8 days. This difference could be related, not only to groundnut variety used, but also to their study's conditions. As far as larval stages are concerned, four distinct larval stages were given as reported [12]. Our results indicate that larval stage duration varies from one stage to another; which was not the case with the results reported by some authors who found a 4 days average duration for the first three larval stages [13]. This constant duration has something to do with the climatic conditions, mainly with temperature [15]; they consider the latter as the main factor which determines insects' larval development. In addition to this factor, insect used variety and biotype can also influence this development period. Variations in larval stages duration or their number may suggest the presence of a biotype [16]. The sex-ratio in favor of females can be explained by a sufficient food supply in quantity and quality for insects during their development [17]. This tendency of $C$. serratus to produce more females explains the scope of infestations observed in groundnut stocks. A 78.9 eggs average laying at $30^{\circ} \mathrm{C}$ suggesting thus that temperature plays a crucial role in groundnut beetle's laying [18].

\subsection{C. serratus Biological Parameters Study on the Wild Host Plants under Laboratory Conditions}

On seeds exposed to $C$. serratus females, the beetle larval development was possible only on 6 (six) plants species which are $T$. indica, $P$. thonningii, B. rufescens, A. hypogea (seeds and pods) C. sieberiana and F. albida. Similar results were reported [19] [20] 
[21]; however, these authors do not report a C. serratus larval development on F. albi$d a$ 's seeds. For these authors, F. albida permits only the development of the Caryedon species called Caryedon excavatus which in fact exploits the latter under natural conditions. Lale and Igwebuike [22] explain that F. albida's pods in Nigeria Savannas are infested by the $C$. serratus species. This situation indicates that this $C$. serratus species can lay and develop on $F$. albida's seeds. C. serratus larval development failure on other plants' seeds can be justified by the structure of these plants' teguments. In fact, certain plants seminal tegument rich in tannins and lignin can constitute a chemical barrier against beetle larvae penetration [23] [24] [25]. The results on the development time show the importance of the laying substrate on larvae development. The development duration is faster on $F$. albida's seeds compared to other seeds, suggesting that this plant can be a natural host plant for C. serratus. C. serratus laying behavior reveals that whatever the conditions, $C$. serratus females lay on more than half of the species to which they are exposed. These results suggest that $C$. serratus females seem to have little requirement as far as the laying substrate is concerned [7] [10]. However, $90 \%$ of the insects from Bruchidae family species to which the $C$. serratus belongs lay and develop at the expense of leguminous plants [2]. In our results, the majority of laying is observed on leguminous plants. Laying comparison according to the botanical family indicates that $C$. serratus females laid more eggs on Ceasalpiniaceae than on other host plants families. This female's attraction by Ceasalpiniaceae is due to the weakness of the chemical defenses met in this family [26] but also to the chemical composition is the major index which intervenes in the host selection process by insects [27].

\subsection{Pods Size Influence on C. serratus Adult's Morphology}

Considering the aspect of the groundnut pods, the laying was possible preferentially on three-seeds pods. These observations are similar to those by Mitchell who observed the same laying behavior with the cowpea beetle Callosobruchus maculatus [28]. The choice of groundnut three-seed pods by females can be explained by a more important availability of feeding support for larvae [9]. With the cowpea beetle, female's fertility is related to seeds number offered to them [29]. In the case of the groundnut beetle, it can be supposed that females laying respects conditions observed in cowpea beetle case. As far as the survival rate of larvae is concerned, more than half of laid eggs evolves to give adults, whatever the pod size; suggesting that this parameter does not have an influence on emergence rate.

\section{Conclusions}

The study of biological parameters $C$. serratus showed that the larval insect development was possible only on six plant species. The presence of these plant species in three agro-ecological zones of the country, explains the maintenance of the insect in these areas.

The study of $C$. serratus biology laboratory has shown that the insect development time (egg-adult) varies according to the laying substrate. Females showed a period of 
relatively short pre oviposition, and 24 hours after their emergence spawning activity begins. The morphometric of adult $C$. serratus showed that insects which have emerged from the different types of groundnut pods have not presented significantly different size.

\section{Competing Interest}

Authors have declared that no competing interests exist.

\section{References}

[1] Anonyme (1991) Memento de l'agronome. L'arachide. Quatrieme Edition. Collection Techniques Rurales en Afrique, 867-880.

[2] Southgate, B.J. (1979) Biology of the Bruchidae. Annual Review of Entomology, 24, 449473. http://dx.doi.org/10.1146/annurev.en.24.010179.002313

[3] Sembene, M. (2000) Variabilite de l'espaceur transcrit (ITS1) de l'ADN ribosomique et polymorphisme des locus microsatellites chez la bruche Caryedon serratus (Olivier): Differenciation en races d'hotes et infestation de l'arachide au Senegal. hese de Doctorat These de Doctorat d'Etat es sciences. Universite Cheick Anta Diop de Dakar, 128 p.

[4] Ouedraogo, I. (2011) Biologie et ecologie de Caryedon serratus olivier (Coleoptera: Chrysomelidae) dans un ecosysteme arachidier de l'ouest du Burkina Faso. These de Doctorat. Univ de Ouagadougou, Burkina Faso, 120 p.

[5] Diome, T., Ndong, A., Kebe, K., Thiaw, C., Ndiaye, A., Doumma, A., Sanon, A., Ketoh, G. Sembene, M. (2013) Effect of Agro-Ecological Zones and Contiguous Basin Crops of Groundnut (Arachis hypogaea) on the Structuring and Genetic Diversity of Caryedon serratus (Coleoptera: Chrysomelidae, Bruchinae) in the Sub-Region of West Africa. Journal of Asia-Pacific Entomology, 16, 209-217. http://dx.doi.org/10.1016/j.aspen.2013.01.004

[6] Decelle, J. (1966) Bruchus serratus O L. 1790. Especes type du genre Caryedon Schonherr, 1823 Rev. Zool.bot.afr. LXXIV; 1-2, 169-173.

[7] Robert, P. (1984) Contribution a l'etude de l'ecologie de la bruche de l'arachide: Caryedon serratus Ol. (Coleoptera, Bruchidae), sur ses differentes plantes hotes. These de $3 \mathrm{e}$ cycle, Universite Francois Rabelais de Tours, France, 122 p.

[8] Delobel, A., Tran, M. and Sembene, M. (2000) Influence du choix alimentaire sur la fecondite et le developpement larvaire des Caryedon des legumineuses (Coleoptera: Bruchidae) au Senegal. Annales Societe Entomologique de France (NS), 36, 61-73.

[9] Sembene, M., Kebe, K., Delobel, A. and Rasplus, J.Y. (2010) Phylogenetic Information Reveals the Peculiarity of Caryedon serratus (Coleoptera, Chrysomelidae, Bruchinae) Feeding on Cassia sieberiana DC (Caesalpinioideae). African Journal of Biotechnolog, 9, 1470-1480.

[10] Ndiaye, S. (1991) La bruche de l'arachide dans un ecosysteme du centre Ouest du Senegal: Contribution a l'etude de la contamination en plein champ et dans les stocks de l'arachide par aryedonserratus (ol.) (Col., Bruchidae); role des legumineuses hotes sauvages dans le cycle de cette bruche. These de Universite de Pau et des pays de l'Adour, France, 96 p.

[11] Lafleur, G. (1994) Effet des pyrethrinoides, du neem, de la terre diatomee et de l'enfumage sur la bruche de l'Arachide. Sahel PV info $\mathrm{N}^{\circ} 66$ : 9-14.

[12] Prevett, P.F. (1965) The Genus Caryedon in Northern Nigeria, with Descriptions of Six New Species (Col. Bruchidae). Annales de la Société Entomologique de France (N.S), 1, 523-547.

[13] Rama, D.D. and Venugopal, N.R. (2005) Some Observations on the Biology of Groundnut 
Seed Beetle Caryedon serratus (Olivier) (Coleoptera: Bruchidae). Legume Research, 28, 229-230.

[14] Ahmed Abdel Moniem Abdel Razig (2014) Biological Studies on The Groundnut Seed Beetle Caryedon serratus (Coloeoptera: Bruchidae). Persian Gulf Crop Protection, 3, 110114. www.cropprotection.ir

[15] Abass, A., Kontodimas, D.C. and Mcneill, M. (2008) Modeling Embryo Development of Sitona discoideus Gyllenhal (Coleoptera: Curculionidae) under Constant Temperature. Environmental Entomology, 37, 1381-1388. http://dx.doi.org/10.1603/0046-225X-37.6.1381

[16] Pantoja, A., Salazar, A. and Macchiavelli, R. (2006) Recognition of Instars and Adult Trap Catches of Cosmopolites sordidus (Coleoptera: Curculionidae) from Plantains in Puerto Rico. Annals of the Entomological Society of America, 99, 875-878. http://dx.doi.org/10.1603/0013-8746(2006)99[875:ROIAAT]2.0.CO;2

[17] Dabire, C. (2001) Etude de quelques paramètres biologiques et écologiques de Clavigralla tomentosicollis STAL., (Hemiptera: Coreidae) punaises suceuses des gousses du niébé ((Vigna unguiculata (L.)) dans une perspective de lutte durable contre l'insecte au Burkina Faso.Thèse de doctorat d'Etat, Université de Cocody, Cocody, 179 p.

[18] Delobel, A. (1989) Influence des gousses d'arachide (Arachis hypogea L.) et de l'alimentation imaginale sur l'ovogenèse, l'accouplement et la ponte chez la bruche Caryedon serratus. Entomologia Experimentalis et Applicata, 52, 281-289.

http://dx.doi.org/10.1111/j.1570-7458.1989.tb01278.x

[19] Delobel, A., Tran, M. and ET Sembene, M. (2000) Influence du choix alimentaire sur la fécondité et le développement larvaire des Caryedon des légumineuses (Coleoptera: Bruchidae) au Sénégal. Annales de la Société Entomologique de France, 36, 61-73.

[20] Sembene, M. and et Delobel, A. (2004) Mythe ou réalité? Le "Principe de Hopkins" dans le cas de la Bruche de l'arachide Caryedon serratus (Olivier) (Coleoptera: Bruchidae). Bulletin de la Société Entomologique de France, 109, 61-66.

[21] Sembene, M., Thiaw, C., Doumma, A., Sanon, A., Ketoh, G.K. and Delobel, A. (2012) Preference de ponte et niveaux d'adaptation de differentes souches de Caryedon serratus Ol. (Coleoptera: Bruchidae) a l'arachide (Arachis hypogaea L., Fabaceae). Annales de la Société Entomologique de France, 48, 106-114. http://dx.doi.org/10.1080/00379271.2012.10697758

[22] Lale, N.E.S. and Igwebuike, J.U. (2002) Field Infestation of Faidherbia (Acacia) albida (Del.) A. Chew. Pods by Stored Product Coleoptera in the Nigerian Savanna and Effect of Infestation on Nutrient Quality. Journal of Arid Environments, 51, 103-112. http://dx.doi.org/10.1006/jare.2001.0898

[23] Dobie, P., Dendy, J., Sherman, C., Padgham, J., Wood, A. and Et Gatehouse, A.M.R. (1990) New Sources of Resistance to Acanthoscelides obtectus and Zabrotes subfasciatus in Mature Seeds of Five Species of Phaseolus. Journal of Stored Products Research, 26, 177-186. http://dx.doi.org/10.1016/0022-474X(90)90020-S

[24] Bougdad, A., Gillion, Y. and Gagnepain, E.T.C. (1986) Influence du tégument des graines mûres de Vicia faba sur le développement larvaire de Callosobruchus maculatus. Entomologia Experimentalis et Applicata, 42, 219-223. http://dx.doi.org/10.1111/j.1570-7458.1986.tb01025.x

[25] Bougdad, A., Gillion, Y. and Gagnepain, E.T.C. (1987) Valeur trophique des Acides aminés dans les graines de légumineuses et développement larvaire de Callosobruchus maculatus. Biochemical Systematics and Ecology, 15, 427-432. http://dx.doi.org/10.1016/0305-1978(87)90056-1

[26] Gillon, Y., Rasplus, J.Y., Bougdad, A. and Mainguet, A.M. (1992) Utilisation de légumine- 
uses par un peuplement de Bruchidae d'Anthribidae (Coleoptera) en zone de mosaïque forêt-savane. Journal of African Zoology, 106, 421-443.

[27] Courtney, S.P. and Kibota, T.T. (1991) Mother Doesn't Know Best: Selection of Hosts by Ovipositing Insects. In: Bernays, E.A., Ed., Insect-Plant Interactions, Vol. 2, CRC Press, Boca Raton, 161-187.

[28] Mitchell, R. (1975) The Evolution of Oviposition Tactics in the Bean Weevil, Callosobruchus maculatus (F.). Ecology, 56, 696-702. http://dx.doi.org/10.2307/1935504

[29] Credland, P.F. (1986) Effect of Host Availability on Reproductive Performance in Callosobruchus maculatus (F.) (Coleoptera: Bruchidae). Journal of Stored Products Research, 22, 49-54. http://dx.doi.org/10.1016/0022-474X(86)90047-0

Submit or recommend next manuscript to SCIRP and we will provide best service for you:

Accepting pre-submission inquiries through Email, Facebook, LinkedIn, Twitter, etc. A wide selection of journals (inclusive of 9 subjects, more than 200 journals)

Providing 24-hour high-quality service

User-friendly online submission system

Fair and swift peer-review system

Efficient typesetting and proofreading procedure

Display of the result of downloads and visits, as well as the number of cited articles

Maximum dissemination of your research work

Submit your manuscript at: http://papersubmission.scirp.org/

Or contact ae@scirp.org 